\title{
Explaining the effect of a 1 -year intervention promoting physical activity in middle schools: a mediation analysis
}

\author{
L Haerens ${ }^{1}$, E Cerin ${ }^{2}$, L Maes ${ }^{3}$, G Cardon ', B Deforche ${ }^{1}$ and I De Bourdeaudhuij ${ }^{1, *}$ \\ 'Department of Movement and Sport Sciences, Ghent University, Watersportlaan 2, B-9000 Ghent, Belgium: \\ ${ }^{2}$ Institute of Human Performance, University of Hong Kong, Hong Kong SAR, People's Republic of China: \\ ${ }^{3}$ Department of Public Health, Ghent University, Ghent, Belgium
}

Submitted 20 September 2006: Accepted 4 June 2007: First published online 6 September 2007

\begin{abstract}
Objective: The aim of the present study was to examine the mediation effects of changes in psychosocial determinants of physical activity (attitude, social support, self-efficacy, perceived benefits and barriers) on changes in physical activity. Design: One-year intervention study with baseline and 1-year post measures of physical activity habits and psychosocial correlates.

Setting: Fifteen middle schools.

Subjects: Boys and girls $(n=2840)$ aged $11-15$ years completed the validated questionnaires during class hours.

Results: The product-of-coefficients test was used to asses the mediating effects. Self-efficacy for physical activity at school was found to be the only significant mediator of physical activity change. Specifically, self-efficacy for physical activity at school partly mediated the effect of the intervention on total and school-related physical activity change in the intervention group with parental support $(P<0.05)$. None of the other potential mediators, attitudes, social support, perceived benefits and perceived barriers, seemed to have had a positive effect. Even a suppressor effect was found for attitudes. Given that the effects of self-efficacy and attitudes were of opposite direction, the total mediated/suppressed effects of the intervention were not statistically significant.

Conclusions: Positive changes in total and school-related physical activity in adolescents could be partly explained by increases in self-efficacy for physical activity at school through a physical activity intervention in middle schools with parental support. However, the suppressor effect of attitudes decreased this effect. As this is one of the first true mediation analyses in this age group, further research is needed to replicate the importance of these mediators.
\end{abstract}

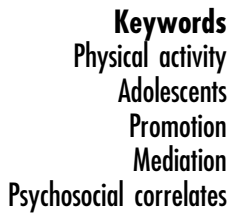

The health benefits of regular physical activity are well documented in all age groups ${ }^{1}$. Nevertheless, a sedentary lifestyle among adolescents, adults and older persons is prevalent in almost all parts of the Western world ${ }^{2,3}$. In particular, a steep decline in activity levels occurs during adolescence $^{4}$. Therefore, it is important to promote maintenance of adequate physical activity levels in adolescents or to encourage inactive adolescents to become more active.

As interventions to encourage physical activity have to be based upon the most important processes or determinants of physical activity in adolescents, studying physical activity determinants in this age group is the first step to be taken. Most studies investigated these determinants based on generic theories or models such as Social Cognitive Theory and social-psychological theories such as the Theory of Planned Behaviour ${ }^{5,6}$. Results of these studies showed that physical activity in adoles- cence was best predicted by self-efficacy, attitudes or beliefs, family or friend support, and perceived benefits and barriers ${ }^{7-9}$. Once there is enough knowledge on the determinants of physical activity in this age group, a second step can be taken: the development and evaluation of physical activity interventions.

Intervention studies promoting physical activity in adolescents are relatively scarce ${ }^{10,11}$. The school environment is often considered to be the ideal setting for implementing these interventions as all students can easily be reached, education can be included in the regular curriculum and in physical education courses, and schools often have the facilities and accommodation to provide opportunities for adolescents to be physically active ${ }^{12-14}$. In the USA, two intervention studies promoting physical activity in middle schools have been conducted: the Planet Health Study ${ }^{15}$ and the M-Span study ${ }^{16}$. Results were mixed and often different for boys 
and girls. In Europe, good results were recently found in the ICAPS study (Intervention Centred on Adolescents' Physical activity and Sedentary behaviour) showing increases in activity levels in boys and girls in France ${ }^{17}$. Positive results were also found in our own Belgian study, aimed at increasing activity levels in adolescents through middle schools ${ }^{18}$. Results showed significant increases in physical activity levels in the intervention conditions, when compared with the control group, in both boys and girls. All of these interventions were developed based on health promotion planning models ${ }^{19,20}$. They are based on theories that assume that the intervention succeeds in changing physical activity behaviour through changes in the theoretical constructs or the determinants that precede this behaviour. However, this assumption is rarely tested. Very few studies have examined possible mediators in effective physical activity interventions ${ }^{21}$. The question asked here is about the mechanisms underlying behavioural change: 'how' does the intervention work? From the review of Lewis et $a l^{22}$ on psychosocial mediators of physical activity behaviour among adults and children, it was concluded that only two studies conducted a complete mediator analyses, both using adult participants. A possible explanation for this lack of studies is that a full mediation analysis can only be executed if a true control group is available, if physical activity differences are found between the intervention and control groups, and if a prospective design is used (changes in mediators effect changes in outcome). All three requirements were met in our own Belgian intervention study in middle schools. By examining several potential mediators in this intervention study, we may learn which mediators are most effective for increasing physical activity in adolescents. In other words, it may clarify how the intervention worked but also it may reveal if the intervention was unsuccessful in changing potential important mediators of physical activity change.

The aim of the present study was to examine mediation effects of changes in psychosocial determinants of physical activity (attitude, social support, self-efficacy, perceived benefits and barriers) on changes in physical activity, using a 1-year prospective intervention study, including programmes with and without parental support, in middle schools. As the intervention was developed to change all of these underlying constructs, it was hypothesised that changes in these constructs would act as a mediator in predicting changes in physical activity from baseline to 1-year follow-up.

\section{Methods}

\section{Procedure and participants}

In the present study a random sample of 15 schools out of the 65 Flemish schools with technical and vocational education in West Flanders (Belgium) was selected.
Principals of 23 schools were approached by telephone to obtain 15 who agreed to participate in the study. The 15 schools willing to participate were then randomly assigned to the intervention or control conditions, each with five schools: (1) intervention with parental support; (2) intervention alone; and (3) control condition. The parents of all 2991 students in seventh and eight grades received an informed consent form in which the authorisation was asked for their child to complete measurements. The parents of 151 (5\%) students gave no permission for their child to participate in this study. This resulted in a sample of 2840 11-15-year-old boys $(n=1800)$ and girls $(n=1040)$ within 15 schools. The study protocol was approved by the Ethical Committee of Ghent University. A more detailed description of the sample and procedure is given elsewhere ${ }^{18,23}$.

\section{Measures}

Measures were performed at the beginning (September 2003) and at the end of the school year (June 2004).

\section{Physical activity}

Physical activity levels were determined using a selfadministered questionnaire at school, based on the Flemish Physical Activity Questionnaire (FPAQ). This questionnaire asked for minutes of activity of different types (sports, transport) and within different contexts (leisure time, school). Five indices were computed: a total physical activity index and its components - namely, active transportation to/from school, school-related sporting activities, leisure-time active transportation, and leisure-time sporting activities. The sporting activities indices referred to the time spent in sports at school (school-related sporting activities) and during leisure time (leisure-time sporting activities). Based on the metabolic equivalent task (MET) values from the Compendium of Physical Activities ${ }^{24}$, each sport with a metabolic rate lower than 3 MET was classified as an activity of low intensity and was not taken into account for the sports index. The active transportation indices referred to the time spent in leisure-time active transportation and in walking and cycling to and from school. The 'total physical activity index' was computed by summing the minutes of all four activities.

Philippaerts and colleagues ${ }^{25}$ reported moderate to high reliability of the FPAQ for the different indices used in the present study. The test-retest intra-class correlation coefficients (ICCs) exceeded 0.70. To obtain validity measures, data from the questionnaire were correlated to data derived from accelerometers (model 7164; Computer Science Application, Inc.). Pearson correlations were significant for all activity measures and ranged between 0.43 and 0.79 , indicating acceptable validity of the instrument. In the present study, the ICCs of the physical activity measures (pre- and post-intervention) in the 
control group were 0.52 for total physical activity, 0.40 for school-related sporting activities, 0.60 for active transportation to/from school, 0.50 for leisuretime sporting activities, and 0.31 for leisure-time active transportation.

\section{Physical activity determinants}

General-affective attitudes, social support, self-efficacy, and perceived benefits and barriers were assessed by 30 items with a 5-point scale. Questions were selected and adopted from previous studies with adolescents and adults ${ }^{9,26}$. General-affective attitudes (four items) towards physical activity were assessed using bipolar adjectives. Participants were asked whether sports and physical activity are: 'not pleasant - pleasant', 'bad - good', 'healthy - unhealthy' and 'dangerous - safe'. Social support (four items) was assessed by asking respondents how frequently their parents, brothers and sisters, friends and teachers encouraged them to be physically active. Self-efficacy (two items) was measured by asking how easy or difficult it is to be active at their school or at their home. Perceived benefits and barriers with regard to physical activity were investigated by asking respondents to rate their agreement with possible effects of sports and physical activity (eight items: weight and physical appearance, health and fitness, social interaction, pleasure, competition, stress and depression, admiration of others, relaxation from (school)work) and the frequency with which barriers prevented them from exercising (11 items: lack of time, lack of discipline, lack of interest, health problems, personal problems, not skilled enough, too expensive, no transportation, not liking to sweat, fear of being laughed at, lack of facilities at school). Factor analyses of these five scales yielded a general attitude factor; two perceived benefits factors (health and psychosocial benefits); three perceived barriers factors (motivational, health and environmental barriers); two single-item self-efficacy factors (self-efficacy for physical activity at school and at home); and a general social support factor.

Several measures of social support were constructed to reflect the fact that different sources of social support may be important to the various indices of physical activity change and intervention modes (presence or absence of parental support). Thus, total social support (combining support from family, friends and teachers) was hypothesised to be important to changes in total physical activity; social support from family and friends to changes in leisure-time physical activity; social support from friends and teachers to school-related physical activities; and social support from parents to changes in school-related physical activities in the intervention group with parental support.

In this study, Cronbach's alpha coefficients of internal consistency for the mediating variable scales were 0.73 for attitudes (four items); 0.76 for total social support (four items); 0.77 for social support from family and friends (three items); 0.58 for social support from friends and teachers (two items); 0.54 for perceived health benefits (two items); 0.80 for perceived psychosocial benefits (six items); 0.78 for motivational barriers (seven items); 0.64 for health barriers (two items); and 0.59 for environmental barriers (three items).

\section{Intervention}

The school-based intervention programme was developed to promote healthy food choices and physical activity engagement in order to prevent the increasing prevalence of overweight in adolescents. The effects of the intervention on adiposity indices ${ }^{23}$, adolescents' diet ${ }^{27}$ and physical activity ${ }^{18}$ are beyond the scope of the present study and are published elsewhere.

The intervention was designed to be implemented by the school staff itself with only minimal external support, to make later implementation feasible. It was coordinated by a working group of school personnel that received background information, an intervention manual and educational material from the researchers. The physical activity intervention had two main components: an environmental part and an individual-based part. The physical activity environmental intervention focused on increasing levels of moderate to vigorous physical activity to at least $60 \mathrm{~min}$ a day by: (1) creating more opportunities to be physically active during breaks, at noon or after school hours and by varying the content of the physical activities offered in order to reach all students; (2) providing extra sports materials at noon, after school hours and during breaks; and (3) encouraging active transportation (walking and cycling) to school. At the personal level, students completed the computer-tailored physical activity intervention adapted for adolescents ${ }^{28,29}$ during one class hour, which resulted in immediate personal feedback about physical activity and sports for each student.

The goal of the involvement of the parents in half of the experimental schools was to create a supportive environment for healthy behaviours outside school. Parents were invited to come to an interactive meeting on physical activity and healthy food habits. As expected, the attendance was typically low. Hence, in order to reach all parents, the information was also communicated through home correspondence; i.e. it was published in the school papers and newsletters for the parents. In addition all parents received a $\mathrm{CD}-\mathrm{ROM}$ with the adult computertailored intervention for physical activity to accomplish at home. Through an informative folder parents were informed that their child accomplished the same test at school. They were asked to discuss the results together and to give their child support to create an active lifestyle, if necessary. A thorough description of the physical activity intervention is given elsewhere ${ }^{18,23}$. 


\section{Statistical analyses}

Changes in the attitudes, social support (total, from family and friends, and from peers and teachers), self-efficacy (for physical activity at school and at home), perceived benefits (health and psychosocial) and perceived barriers (motivational, health and environmental) were examined as potential mediators of the intervention effects on changes in physical activity.

Measures of change in physical activity between preand post-test were created by regressing the physical activity measures at post-test onto their baseline values to compute residualised physical activity change indices. The resulting residualised scores can be interpreted as the amount of increase or decrease in physical activity between baseline and post-test, independent of baseline activity. Similarly, a measure of change of psychosocial determinants was recreated by regressing each psychosocial determinant score at post-test onto the baseline scores. These measures of change in psychosocial variables are independent of baseline determinants scores, and can be considered to be dynamic variables that covary with changes in physical activity (see Sallis et al. ${ }^{30}$ for a further explanation of the use of residualised change scores).

To assess mediating effects, a product-of-coefficient test appropriate for cluster-randomised controlled trials was used ${ }^{31}$. This tests consists of: (1) estimating the effect of the intervention on changes in the potential mediator ( $\alpha$ coefficient) by regressing changes in the mediator onto the intervention; (2) estimating the independent effect of changes in the potential mediator on changes in the outcome ( $\beta$ coefficient) by regressing changes in the outcome onto the intervention and changes in the mediator; (3) computing the product of the two coefficients $(\alpha \beta)$, representing the mediated effect; and (4) dividing $\alpha \beta$ by its standard error. These estimates were obtained using two-level linear regression models, accounting for within-school cluster effects. The first step in the analysis represents a formal test of whether the intervention was successful in changing the targeted mediators (action theory test), while the second step represents a formal test of whether the changes in the mediator predict changes in the outcome (conceptual theory test). As the outcome variables were skewed, Huber/White robust estimates of standard errors were used.

Although this intervention was meant to simultaneously target multiple mediators, both single- and multiple-mediator models were assessed ${ }^{32}$, the reason being that the effect of a specific mediator in a multiplemediator model may be obscured by the presence of multicollinearity ${ }^{33}$. The multiple-mediator models examined the independent effects of mediating variables that were found to be statistically significant mediators or suppressors in the single-mediator models. Finally, the magnitude of the total mediated effect and ratios of mediated to total intervention effects were also estimated.
The standard error of the total mediated effect was computed using the multivariate delta method, i.e. by pre- and post-multiplying the covariance matrix among $\alpha$ and $\beta$ parameters of the function (sum of five mediating effects) by a vector of partial derivatives of the function ${ }^{34}$. Separate mediating variable analyses were conducted for the intervention groups with and without parental support. These analyses were performed using MLwiN version 2.02 and Microsoft ${ }^{\circledR}$ Excel.

\section{Results}

\section{Power analyses}

The within-cluster correlations and study design effects for residualised changes in hypothetical mediating variables ranged from 0.01 to 0.08 , and from 2.80 to 15.4 , respectively (effective sample size ranging from 158 to 868). This means that, adopting a significance level of 0.05 , the power of the study to detect moderate-to-large mediating effects (defined as a standardised changes of 0.39 and 0.59; Cohen, 1988 ${ }^{35}$ ) was 0.99. Also, the study had acceptable power $(>0.80)$ to detect small mediation effects (standardised change of 0.14) of self-efficacy for physical activity outside school, attitudes, perceived health benefits, psychosocial benefits, motivational barriers and health barriers.

\section{Mediation analyses}

\section{Intervention effect}

On average, the intervention with parental support group increased their total physical activity by 9.0 min day $^{-1}$ (95\% confidence interval (CI): 2.9, 15.2; $P=0.004$ ) more than did the control group (Table 1). Significant differences were also found between the intervention group with parental support and the control group on changes in active transportation to/from school ( 2.1 min day $^{-1}$; 95\% CI: 0.6, 3.6; $P=0.006)$ and changes in school-related sporting activities (2.1 minday ${ }^{-1} ; \quad 95 \%$ CI: $0.5, \quad 3.7$; $P=0.012$ ). No significant differences were found between the control group and intervention group without parental support (Table 1).

\section{Action theory test}

When compared with the control group, the intervention programme without parental support appeared to have a negative effect on changes in attitudes $(P<0.001)$, selfefficacy for physical activity at home $(P<0.01)$, perceived health benefits $(P<0.01)$, and perceived environmental $(P<0.01)$ and motivational barriers $(P<0.05)$ (Table 2$)$. In contrast, a positive effect of the intervention programme with parental support on changes in self-efficacy for physical activity at school was observed $(P<0.05)$. Also, this intervention condition was associated with a significantly smaller negative effect on attitudes $(-0.061$; 
Table 1 Intervention effects on five physical activity indices (residualised change scores)

\begin{tabular}{|c|c|c|c|c|}
\hline \multirow[b]{2}{*}{ Physical activity index } & \multicolumn{2}{|c|}{ Intervention without parental support $\left(\min\right.$ week $\left.^{-1}\right)$} & \multicolumn{2}{|c|}{ Intervention with parental support (min week $\left.{ }^{-1}\right)$} \\
\hline & $b(\mathrm{SE})$ & $95 \% \mathrm{Cl}$ & $b(\mathrm{SE})$ & $95 \% \mathrm{Cl}$ \\
\hline Total physical activity & $3.6(3.6)$ & $-3.7,10.4$ & $9.1(3.1)$ & $2.9,15.2^{\star \star \star}$ \\
\hline Active transportation to/from school & $1.4(0.9)$ & $-0.3,3.2$ & $2.1(0.8)$ & $0.6,3.6^{\star \star \star}$ \\
\hline School-related sporting activities & $1.1(0.9)$ & $-0.8,2.9$ & $2.1(0.8)$ & $0.5,3.7^{\star \star}$ \\
\hline Leisure-time active transportation & $1.3(1.0)$ & $-0.8,3.3$ & $1.1(0.9)$ & $-0.6,2.9$ \\
\hline Leisure-time sporting activities & $-0.5(2.7)$ & $-5.9,4.9$ & $3.2(2.4)$ & $-1.5,7.8$ \\
\hline
\end{tabular}

$b$ - regression coefficient; SE - standard error; $95 \% \mathrm{Cl}-95 \%$ confidence interval.

All models adjusted for gender, age, household socio-economic status, and within-school cluster effects.

${ }^{\star \star} P<0.05 ;{ }^{* \star \star} P<0.01$.

Table 2 Action theory tests: intervention effects on mediators (residualised change scores)

\begin{tabular}{|c|c|c|c|c|}
\hline \multirow[b]{2}{*}{ Mediator } & \multicolumn{2}{|c|}{ Intervention without parental support } & \multicolumn{2}{|c|}{ Intervention with parental support } \\
\hline & $\alpha(\mathrm{SE})$ & $95 \% \mathrm{Cl}$ & $\alpha(\mathrm{SE})$ & $95 \% \mathrm{Cl}$ \\
\hline Attitude & $-0.171(0.037)^{\star \star \star \star}$ & $-0.244,-0.098$ & $-0.061(0.032)^{\star \star \star}$ & $-0.124,-0.002$ \\
\hline Self-efficacy - physical activity at school & $-0.131(0.085)$ & $-0.298,0.036$ & $0.169(0.076)^{\star \star}$ & $0.020,0.318$ \\
\hline Self-efficacy - physical activity at home & $-0.162(0.061)^{\star \star \star}$ & $-0.282,-0.042$ & $-0.074(0.052)$ & $-0.176,0.028$ \\
\hline Social support - total & $0.049(0.072)$ & $-0.092,0.190$ & $-0.005(0.063)$ & $-0.128,0.118$ \\
\hline Social support - family \& friends & $-0.005(0.073)$ & $-0.040,0.270$ & $-0.032(0.064)$ & $-0.087,0.187$ \\
\hline Social support - friends \& teacher & $0.115(0.079)$ & $-0.148,0.138$ & $0.050(0.070)$ & $-0.157,0.093$ \\
\hline Social support - parents & $-0.096(0.086)$ & $-0.265,0.073$ & $-0.080(0.075)$ & $-0.227,0.067$ \\
\hline Benefits - health & $-0.203(0.068)^{\star \star \star}$ & $-0.336,-0.070$ & $-0.061(0.059)$ & $-0.177,0.055$ \\
\hline Benefits - psychosocial & $-0.104(0.055)$ & $-0.212,0.004$ & $-0.003(0.047)$ & $-0.095,0.089$ \\
\hline Barriers - health & $0.088(0.068)$ & $-0.045,0.221$ & $0.021(0.060)$ & $-0.097,0.139$ \\
\hline Barriers - environmental & $0.190(0.061)^{\star \star \star}$ & $0.070,0.310$ & $-0.029(0.054)$ & $-0.135,0.077$ \\
\hline Barriers - motivational & $0.132(0.056)^{\star \star}$ & $0.022,0.242$ & $0.001(0.049)$ & $-0.095,0.097$ \\
\hline
\end{tabular}

$\alpha$ - estimate of unstandardised regression coefficient of intervention effect on residualised change score of psychosocial factors; SE - standard error; $95 \% \mathrm{Cl}-$ $95 \%$ confidence interval.

All models adjusted for gender, age, household socio-economic status, and within-school cluster effects.

${ }^{\star \star} P<0.05 ;{ }^{\star \star \star} P<0.01 ;{ }^{\star \star \star \star} P<0.001$.

95\% CI: $-0.124,-0.002)$ than the intervention programme without parental support $(-0.171 ; 95 \% \mathrm{CI}$ : $-0.244,-0.098)$.

\section{Conceptual theory tests}

With the exception of perceived health barriers, and irrespective of experimental condition, changes in all psychosocial factors were significantly and strongly associated in the expected direction with changes in total physical activity (all $P<0.01$; Table 3 ). Similar findings were observed for school-related and leisure-time sporting activities, and leisure-time active transportation. Changes in attitude, perceived psychosocial benefits and perceived motivational barriers were associated in the expected direction with changes in active transportation to/from school. However, the associations of changes in active transportation to/from school with changes in social support from friends and teachers and perceived health barriers were opposite to those expected (Table 3).

\section{Mediated effects}

None of the examined psychosocial factors showed a significant mediating effect on changes in physical activity in the intervention group without parental support (Tables 4 and 5, first part). Unexpectedly, significant suppression effects of attitudes, self-efficacy, perceived benefits and perceived barriers on changes in total physical activity and leisure-time physical activity were found. Attitudes, perceived benefits and perceived barriers also suppressed the effect of the intervention (without parental support) on school-related physical activity (Tables 4 and 5). The total suppressed effect of the intervention amounted to 3.31 min day $^{-1}$ (95\% CI: $-4.78,1.84 ; \quad P<0.001)$ of total physical activity; -0.17 minday $^{-1}$ (95\% CI: $\left.-0.28,-0.05 ; P=0.004\right)$ of active transportation to/from school; 0.75 min day $^{-1}$ (95\% CI: $-0.91,-0.60 ; \quad P<0.001)$ of school-related sporting activities; -0.49 min day $^{-1}$ (95\% CI: -0.60 , $-0.37 ; P<0.001)$ of leisure-time active transport; and -2.27 minday $^{-1}$ (95\% CI: $\left.-3.43,-1.11 ; P<0.001\right)$ of leisure-time sporting activities.

While attitudes exerted a suppression effect on changes in physical activity in the intervention group with parental support, self-efficacy for physical activity at school partly mediated the effect of the intervention on total and school-related physical activity change (Tables 4 and 5, second part). Given that the effects of self-efficacy and attitudes were of opposite direction, the total mediated/ suppressed effects of the intervention on changes in total physical activity $\left(-0.39\right.$ min day $^{-1} ; 95 \% \mathrm{CI}:-1.51,0.73$; $P=0.493)$ and school-related physical activity were not 
Table 3 Conceptual theory tests: effects of changes in the mediators on changes in physical activity indices (single-mediator models)

\begin{tabular}{|c|c|c|c|c|c|}
\hline & $\begin{array}{l}\text { Total physical } \\
\text { activity }\end{array}$ & $\begin{array}{l}\text { Active transportation } \\
\text { to/from school }\end{array}$ & $\begin{array}{c}\text { School-related sporting } \\
\text { activities }\end{array}$ & $\begin{array}{l}\text { Leisure-time active } \\
\text { transportation }\end{array}$ & $\begin{array}{l}\text { Leisure-time sporting } \\
\text { activities }\end{array}$ \\
\hline Mediator & $\begin{array}{c}\beta(\mathrm{SE}) \\
(95 \% \mathrm{Cl})\end{array}$ & $\begin{array}{c}\beta(\mathrm{SE}) \\
(95 \% \mathrm{Cl})\end{array}$ & $\begin{array}{c}\beta(\mathrm{SE}) \\
(95 \% \mathrm{Cl})\end{array}$ & $\begin{array}{c}\beta(\mathrm{SE}) \\
(95 \% \mathrm{Cl})\end{array}$ & $\begin{array}{c}\beta(\mathrm{SE}) \\
(95 \% \mathrm{Cl})\end{array}$ \\
\hline Attitude & $\begin{array}{l}15.62(1.74)^{\star \star \star \star *} \\
(12.21,19.04)\end{array}$ & $\begin{array}{r}0.84(0.46)^{\star} \\
(-0.07,1.74)\end{array}$ & $\begin{array}{l}2.68(0.36)^{\star * \star *} \\
(1.97,3.39)\end{array}$ & $\begin{array}{l}1.68(0.46)^{\star * * *} \\
(0.77,2.58)\end{array}$ & $\begin{array}{l}12.54(1.56)^{\star \star \star \star} \\
(9.48,15.61)\end{array}$ \\
\hline Self-efficacy - physical activity at school & $\begin{array}{l}4.99(1.09)^{\star \star \star \star} \\
(2.87,7.12)\end{array}$ & $\begin{array}{r}0.13(0.28) \\
(-0.43,0.68)\end{array}$ & $\begin{array}{l}1.54(0.22)^{\star \star \star \star} \\
(1.10,1.98)\end{array}$ & - & - \\
\hline Self-efficacy - physical activity at home & $\begin{array}{l}9.89(1.06)^{\star \star \star \star} \\
(7.81,11.97)\end{array}$ & - & - & $\begin{array}{l}1.71(0.28)^{\star \star \star \star} \\
(1.16,2.26)\end{array}$ & $\begin{array}{l}8.71(0.95)^{\star \star \star \star} \\
(6.85,10.57)\end{array}$ \\
\hline Social support - total & $\begin{array}{l}2.64(1.19)^{\star \star} \\
(0.31,4.97)\end{array}$ & - & - & - & - \\
\hline Social support - family \& friends & - & - & - & $\begin{array}{l}1.17(0.28)^{\star \star \star \star} \\
(0.62,1.72)\end{array}$ & $\begin{array}{c}2.97(0.97)^{\star} \\
(1.06,4.88)\end{array}$ \\
\hline Social support - friends \& teacher & - & $\begin{array}{l}-0.66(0.29)^{\star \star} \\
(-1.22,0.09)\end{array}$ & $\begin{array}{r}0.40(0.23)^{*} \\
(-0.05,0.85)\end{array}$ & - & - \\
\hline Social support - parents & - & $\begin{array}{r}0.07(0.22) \\
(-0.36,0.50)\end{array}$ & $\begin{array}{r}0.20(0.18) \\
(-0.14,0.55)\end{array}$ & - & - \\
\hline Benefits - health & $\begin{array}{l}2.62(1.07) * * \\
(0.52,4.71)\end{array}$ & $\begin{array}{r}0.11(0.28) \\
(-0.44,0.66)\end{array}$ & $\begin{array}{l}0.64(0.22)^{\star \star \star} \\
(0.20,1.07)\end{array}$ & $\begin{array}{l}0.83(0.28)^{\star \star *} \\
(0.28,1.37)\end{array}$ & $\begin{array}{c}1.85(0.96)^{\star} \\
(-0.03,3.72)\end{array}$ \\
\hline Benefits - psychosocial & $\begin{array}{l}9.11(1.24)^{\star \star \star *} \\
(6.68,11.5)\end{array}$ & $\begin{array}{l}0.82(0.33)^{\star \star} \\
(0.18,1.46)\end{array}$ & $\begin{array}{l}1.60(0.26)^{\star \star \star *} \\
(1.09,2.10)\end{array}$ & $\begin{array}{l}1.24(0.32)^{\star \star \star \star *} \\
(0.60,1.87)\end{array}$ & $\begin{array}{l}7.10(1.11)^{\star \star \star \star} \\
(4.90,9.25)\end{array}$ \\
\hline Barriers - health & $\begin{array}{r}0.37(1.11) \\
(-1.80,2.54)\end{array}$ & $\begin{array}{c}0.51(0.29)^{\star} \\
(-0.05,1.08)\end{array}$ & $\begin{array}{r}-0.33(0.23) \\
(-0.78,0.12)\end{array}$ & $\begin{array}{r}0.36(0.29) \\
(-0.21,0.92)\end{array}$ & $\begin{array}{r}0.24(0.99) \\
(-1.70,2.17)\end{array}$ \\
\hline Barriers - environmental & $\begin{array}{l}-5.54(1.31)^{\star \star * *} \\
(-8.11,-2.96)\end{array}$ & $\begin{array}{r}0.05(0.34) \\
(-0.62,0.72)\end{array}$ & $\begin{array}{l}-1.34(0.27)^{\star \star \star *} \\
(-1.87,-0.80)\end{array}$ & $\begin{array}{l}-0.62(0.34)^{*} \\
(-1.29,0.06)\end{array}$ & $\begin{array}{l}-4.56(1.18)^{\star \star \star \star} \\
(-6.87,2.26)\end{array}$ \\
\hline Barriers - motivational & $\begin{array}{l}-10.90(1.37)^{\star \star \star \star} \\
(-13.58,-8.22)\end{array}$ & $\begin{array}{l}-0.93(0.36)^{\star \star \star} \\
(-1.64,-0.22)\end{array}$ & $\begin{array}{l}-1.51(0.29)^{\star \star \star \star} \\
(-2.08,-0.95)\end{array}$ & $\begin{array}{l}-0.69(0.36)^{*} \\
(-1.40,0.02)\end{array}$ & $\begin{array}{c}-8.71(1.22)^{\star \star \star \star} \\
(-11.11,-6.31)\end{array}$ \\
\hline
\end{tabular}

$\beta$ - estimate of unstandardised regression coefficient of mediator effect on physical activity residualised change score; SE - standard error; $95 \% \mathrm{Cl}-95 \%$ confidence interval. All models adjusted for gender, age, household socio-economic status, intervention, and within-school cluster effects.

${ }^{\star} P<0.10 ;{ }^{\star *} P<0.05 ;{ }^{* \star \star} P<0.01 ;{ }^{* \star \star *} P<0.001$. 
Table 4 Mediating effects of psychosocial determinants on five physical activity indices (single-mediator models)

\begin{tabular}{|c|c|c|c|c|c|}
\hline & $\begin{array}{l}\text { Total physical } \\
\text { activity }\end{array}$ & $\begin{array}{l}\text { Active transportation } \\
\text { to/from school }\end{array}$ & $\begin{array}{c}\text { School-related sporting } \\
\text { activities }\end{array}$ & $\begin{array}{l}\text { Leisure-time active } \\
\text { transportation }\end{array}$ & $\begin{array}{l}\text { Leisure-time sporting } \\
\text { activities }\end{array}$ \\
\hline & $\begin{array}{l}\alpha \beta \text { (SE) } \\
(95 \% \mathrm{Cl}) \\
\% \mathrm{ME}\end{array}$ & $\begin{array}{l}\alpha \beta \text { (SE) } \\
(95 \% \mathrm{Cl}) \\
\% \mathrm{ME}\end{array}$ & $\begin{array}{l}\alpha \beta \text { (SE) } \\
(95 \% \mathrm{Cl}) \\
\% \mathrm{ME}\end{array}$ & $\begin{array}{l}\alpha \beta \text { (SE) } \\
(95 \% \mathrm{Cl}) \\
\% \mathrm{ME}\end{array}$ & $\begin{array}{l}\alpha \beta \text { (SE) } \\
(95 \% \mathrm{Cl}) \\
\% \mathrm{ME}\end{array}$ \\
\hline Mediator & \multicolumn{5}{|c|}{ Intervention group without parental support } \\
\hline Attitude & $\begin{array}{l}-2.67(0.67)^{\star \star \star * *} \\
(-3.98,-1.36) \\
S\end{array}$ & $\begin{array}{l}-0.14(0.04)^{\star \star \star \star} \\
(-0.22,-0.07) \\
S\end{array}$ & $\begin{array}{l}-0.46(0.10)^{\star \star \star *} \\
(-0.66,0.26) \\
S\end{array}$ & $\begin{array}{l}-0.29(0.07)^{\star \star \star \star} \\
(-0.42,-0.15) \\
S\end{array}$ & $\begin{array}{l}-2.14(0.53)^{\star \star \star \star} \\
(-3.19,-1.09) \\
>100\end{array}$ \\
\hline Self-efficacy - physical activity at school & $\begin{array}{l}-0.65(0.44) \\
(-1.53,0.22) \\
-\end{array}$ & $\begin{array}{l}-0.02(0.01) \\
(-0.04,0.01) \\
-\end{array}$ & $\begin{array}{l}-0.20(0.13) \\
(-0.46,0.06) \\
-\end{array}$ & - & - \\
\hline Self-efficacy - physical activity at home & $\begin{array}{l}-1.60(0.63)^{\star *} \\
(-2.84,-0.36) \\
S\end{array}$ & - & - & $\begin{array}{l}-0.28(0.11)^{\star * *} \\
(-0.49,-0.07) \\
S\end{array}$ & $\begin{array}{l}-1.41(0.55)^{\star \star *} \\
(-2.50,-0.32) \\
>100\end{array}$ \\
\hline Social support - total & $\begin{array}{l}0.13(0.19) \\
(-0.25,0.51) \\
-\end{array}$ & - & - & - & - \\
\hline Social support - family \& friends & - & - & - & $\begin{array}{l}-0.01(0.09) \\
(-0.17,0.16) \\
-\end{array}$ & $\begin{array}{l}-0.01(0.22) \\
(-0.44,0.41) \\
3.0\end{array}$ \\
\hline Social support - friends \& teacher & - & $\begin{array}{l}-0.08(0.05) \\
(-0.18,0.03) \\
-\end{array}$ & $\begin{array}{l}0.05(0.03) \\
(-0.02,0.11) \\
-\end{array}$ & - & - \\
\hline Social support - parents & - & $\begin{array}{l}-0.01(0.01) \\
(-0.02,0.01) \\
-\end{array}$ & $\begin{array}{l}-0.02(0.02) \\
(-0.05,0.02) \\
-\end{array}$ & - & - \\
\hline Benefits - health & $\begin{array}{l}-0.53(0.23)^{\star *} \\
(-0.97,-0.09) \\
S\end{array}$ & $\begin{array}{l}-0.02(0.01)^{\star *} \\
(-0.04,-0.00) \\
S\end{array}$ & $\begin{array}{l}-0.13(0.05)^{\star \star *} \\
(-0.22,-0.04) \\
S\end{array}$ & $\begin{array}{l}-0.17(0.06)^{\star \star *} \\
(-0.29,-0.05) \\
S\end{array}$ & $\begin{array}{l}-0.37(0.16)^{\star *} \\
(-0.69,-0.05) \\
75.0\end{array}$ \\
\hline Benefits - psychosocial & $\begin{array}{l}-0.95(0.52)^{*} \\
(-1.96,0.07) \\
S\end{array}$ & $\begin{array}{l}-0.09(0.05)^{\star} \\
(-0.18,0.001) \\
S\end{array}$ & $\begin{array}{l}-0.17(0.09)^{*} \\
(-0.34,0.01) \\
S\end{array}$ & $\begin{array}{l}-0.13(0.07)^{*} \\
(-0.26,0.01) \\
S\end{array}$ & $\begin{array}{l}-0.74(0.40)^{*} \\
(-1.53,0.05) \\
>100\end{array}$ \\
\hline Barriers - health & $\begin{array}{l}0.03(0.03) \\
(-0.04,0.11) \\
-\end{array}$ & $\begin{array}{l}0.05(0.04) \\
(-0.02,0.12) \\
-\end{array}$ & $\begin{array}{l}-0.03(0.02) \\
(-0.07,0.02) \\
-\end{array}$ & $\begin{array}{l}0.03(0.03) \\
(-0.02,0.08) \\
-\end{array}$ & $\begin{array}{l}0.02(0.02) \\
(-0.03,0.07) \\
-\end{array}$ \\
\hline Barriers - environmental & $\begin{array}{l}-1.05(0.40)^{\star \star \star} \\
(-1.84,-0.27) \\
S\end{array}$ & $\begin{array}{l}0.01(0.01) \\
(-0.01,0.02) \\
-\end{array}$ & $\begin{array}{l}-0.25(0.08)^{\star \star \star} \\
(-0.42,-0.09) \\
S\end{array}$ & $\begin{array}{l}-0.12(0.04)^{\star \star \star} \\
(-0.20,-0.04) \\
S\end{array}$ & $\begin{array}{l}-0.74(0.33)^{\star \star \star} \\
(-1.51,-0.22) \\
>100\end{array}$ \\
\hline Barriers - motivational & $\begin{array}{l}-1.44(0.64)^{\star \star} \\
(-2.70,-0.18) \\
S\end{array}$ & $\begin{array}{l}-0.12(0.05)^{\star \star} \\
(-0.23,-0.02) \\
S\end{array}$ & $\begin{array}{l}-0.20(0.09)^{\star \star} \\
(-0.37,-0.03) \\
S\end{array}$ & $\begin{array}{l}-0.09(0.04)^{\star \star} \\
(-0.17,-0.01) \\
S\end{array}$ & $\begin{array}{l}-1.15(0.51)^{\star \star} \\
(-2.16,-0.14) \\
>100\end{array}$ \\
\hline & \multicolumn{5}{|c|}{ Intervention group with parental support } \\
\hline Attitude & $\begin{array}{l}-0.95(0.51)^{\star} \\
(-1.96,0.05) \\
S\end{array}$ & $\begin{array}{l}-0.05(0.03)^{\star} \\
(-0.11,0.00) \\
S\end{array}$ & $\begin{array}{l}-0.16(0.09)^{*} \\
(-0.33,0.01) \\
S\end{array}$ & $\begin{array}{l}-0.10(0.05)^{\star} \\
(-0.21,0.004) \\
S\end{array}$ & $\begin{array}{l}-0.77(0.53)^{\star} \\
(-1.57,0.04) \\
S\end{array}$ \\
\hline
\end{tabular}




\begin{tabular}{|c|c|c|c|c|c|}
\hline & $\begin{array}{l}\text { Total physical } \\
\text { activity }\end{array}$ & $\begin{array}{l}\text { Active transportation } \\
\text { to/from school }\end{array}$ & $\begin{array}{l}\text { School-related sporting } \\
\text { activities }\end{array}$ & $\begin{array}{l}\text { Leisure-time active } \\
\text { transportation }\end{array}$ & $\begin{array}{l}\text { Leisure-time sporting } \\
\text { activities }\end{array}$ \\
\hline Mediator & $\begin{array}{l}\alpha \beta \text { (SE) } \\
(95 \% \mathrm{Cl}) \\
\% \mathrm{ME}\end{array}$ & $\begin{array}{c}\alpha \beta \text { (SE) } \\
(95 \% \mathrm{Cl}) \\
\% \mathrm{ME}\end{array}$ & $\begin{array}{l}\alpha \beta \text { (SE) } \\
(95 \% \mathrm{Cl}) \\
\% \mathrm{ME}\end{array}$ & $\begin{array}{l}\alpha \beta \text { (SE) } \\
(95 \% \mathrm{Cl}) \\
\% \mathrm{ME}\end{array}$ & $\begin{array}{l}\alpha \beta \text { (SE) } \\
(95 \% \mathrm{Cl}) \\
\% \mathrm{ME}\end{array}$ \\
\hline Self-efficacy - physical activity at school & $\begin{array}{l}0.84(0.41)^{\star *} \\
(0.03,1.65) \\
29.1\end{array}$ & $\begin{array}{l}0.02(0.01)^{\star} \\
(-0.002,0.04) \\
1.0\end{array}$ & $\begin{array}{l}0.26(0.12)^{\star \star} \\
(0.03,0.49) \\
12.4\end{array}$ & - & - \\
\hline Self-efficacy - physical activity at home & $\begin{array}{l}-0.73(0.52) \\
(-1.75,0.29) \\
-\end{array}$ & - & - & $\begin{array}{l}-0.13(0.09) \\
(-0.30,0.05) \\
-\end{array}$ & $\begin{array}{l}-0.64(0.46) \\
(-1.54,0.25) \\
-\end{array}$ \\
\hline Social support - total & $\begin{array}{l}-0.01(0.17) \\
(-0.34,0.31) \\
-\end{array}$ & - & - & - & - \\
\hline Social support - family \& friends & - & - & - & $\begin{array}{l}-0.04(0.07) \\
(-0.18,0.11) \\
-\end{array}$ & $\begin{array}{l}-0.10(0.19) \\
(-0.47,0.28) \\
-\end{array}$ \\
\hline Social support - friends \& teacher & - & $\begin{array}{l}-0.03(0.05) \\
(-0.12,0.06) \\
-\end{array}$ & $\begin{array}{l}0.02(0.03) \\
(-0.04,0.08) \\
-\end{array}$ & - & - \\
\hline Social support - parents & - & $\begin{array}{l}-0.01(0.01) \\
(-0.02,0.01) \\
-\end{array}$ & $\begin{array}{l}-0.02(0.02) \\
(-0.05,0.01) \\
-\end{array}$ & - & - \\
\hline Benefits - health & $\begin{array}{l}-0.16(0.16) \\
(-0.47,-0.15) \\
-\end{array}$ & $\begin{array}{l}-0.01(0.01) \\
(-0.02,0.01) \\
-\end{array}$ & $\begin{array}{l}-0.04(0.04) \\
(-0.11,0.04) \\
-\end{array}$ & $\begin{array}{l}-0.05(0.05) \\
(-0.15,0.05) \\
-\end{array}$ & $\begin{array}{l}-0.11(0.11) \\
(-0.33,0.11) \\
-\end{array}$ \\
\hline Benefits - psychosocial & $\begin{array}{l}-0.03(0.43) \\
(-0.87,0.81) \\
-\end{array}$ & $\begin{array}{l}-0.002(0.04) \\
(-0.08,0.07) \\
-\end{array}$ & $\begin{array}{l}-0.005(0.07) \\
(-0.15,0.14) \\
-\end{array}$ & $\begin{array}{l}-0.004(0.06) \\
(-0.12,0.11) \\
-\end{array}$ & $\begin{array}{l}-0.02(0.33) \\
(-0.67,0.63) \\
-\end{array}$ \\
\hline Barriers - health & $\begin{array}{l}0.01(0.02) \\
(-0.04,0.05) \\
-\end{array}$ & $\begin{array}{l}0.01(0.03) \\
(-0.05,0.07) \\
-\end{array}$ & $\begin{array}{l}-0.01(0.02) \\
(-0.06,0.03) \\
-\end{array}$ & $\begin{array}{l}0.01(0.02) \\
(-0.03,0.05) \\
-\end{array}$ & $\begin{array}{l}0.005(0.01) \\
(-0.02,0.03) \\
-\end{array}$ \\
\hline Barriers - environmental & $\begin{array}{l}0.16(0.30) \\
(-0.43,0.75) \\
-\end{array}$ & $\begin{array}{l}-0.001(0.003) \\
(-0.01,0.004) \\
-\end{array}$ & $\begin{array}{l}0.04(0.07) \\
(-0.10,0.18) \\
-\end{array}$ & $\begin{array}{l}0.02(0.03) \\
(-0.05,0.08) \\
-\end{array}$ & $\begin{array}{l}0.13(0.25) \\
(-0.35,0.62) \\
-\end{array}$ \\
\hline Barriers - motivational & $\begin{array}{l}-0.01(0.53) \\
(-1.06,1.03) \\
-\end{array}$ & $\begin{array}{l}-0.001(0.05) \\
(-0.09,-0.09) \\
-\end{array}$ & $\begin{array}{l}-0.002(0.07) \\
(-0.15,0.14) \\
-\end{array}$ & $\begin{array}{l}-0.001(0.03) \\
(-0.07,0.07) \\
-\end{array}$ & $\begin{array}{l}-0.01(0.43) \\
(-0.85,0.83) \\
-\end{array}$ \\
\hline
\end{tabular}

$\alpha \beta$ - product-of-coefficient estimate, mediated effect; SE - standard error; $95 \% \mathrm{Cl}-95 \%$ confidence interval; \% ME - percent of mediated effect (not computed for non-significant effects); S - suppression. ${ }^{\star} P<0.10 ;{ }^{* \star} P<0.05 ;{ }^{* \star \star} P<0.01 ;{ }^{* \star * \star} P<0.001$. 
Table 5 Mediating effects of psychosocial determinants on five physical activity indices (multiple-mediator models)

\begin{tabular}{|c|c|c|c|c|c|}
\hline & $\begin{array}{l}\text { Total physical } \\
\text { activity }\end{array}$ & $\begin{array}{l}\text { Active transportation } \\
\text { to/from school }\end{array}$ & $\begin{array}{c}\text { School-related sporting } \\
\text { activities }\end{array}$ & $\begin{array}{l}\text { Leisure-time active } \\
\text { transportation }\end{array}$ & $\begin{array}{l}\text { Leisure-time sporting } \\
\text { activities }\end{array}$ \\
\hline Mediator & $\begin{array}{l}\alpha \beta \text { (SE) } \\
(95 \% \mathrm{Cl}) \\
\% \mathrm{ME}\end{array}$ & $\begin{array}{l}\alpha \beta \text { (SE) } \\
(95 \% \mathrm{Cl}) \\
\% \mathrm{ME}\end{array}$ & $\begin{array}{l}\alpha \beta \text { (SE) } \\
(95 \% \mathrm{Cl}) \\
\% \mathrm{ME}\end{array}$ & $\begin{array}{l}\alpha \beta \text { (SE) } \\
(95 \% \mathrm{Cl}) \\
\% \mathrm{ME}\end{array}$ & $\begin{array}{l}\alpha \beta \text { (SE) } \\
(95 \% \mathrm{Cl}) \\
\% \mathrm{ME}\end{array}$ \\
\hline & \multicolumn{5}{|c|}{ Intervention group without parental support } \\
\hline Attitude & $\begin{array}{l}-1.26(0.55)^{\star \star} \\
(-2.34,-0.19) \\
S\end{array}$ & $\begin{array}{l}-0.05(0.02)^{\star \star *} \\
(-0.09,-0.01) \\
S\end{array}$ & $\begin{array}{l}-0.30(0.07)^{\star \star \star \star} \\
(-0.44,0.16) \\
S\end{array}$ & $\begin{array}{l}-0.08(0.03)^{\star * *} \\
(-0.13,-0.03) \\
S\end{array}$ & $\begin{array}{l}-0.95(0.29)^{\star * \star} \\
(-1.52,-0.38) \\
>100\end{array}$ \\
\hline Self-efficacy - physical activity at home & $\begin{array}{l}-1.04(0.43)^{\star *} \\
(-1.88,-0.20) \\
S\end{array}$ & - & - & $\begin{array}{l}-0.25(0.10)^{* * *} \\
(-0.45,-0.06) \\
S\end{array}$ & $\begin{array}{l}-0.78(0.32)^{\star *} \\
(-1.40,-0.16) \\
>100\end{array}$ \\
\hline Benefits - health & $\begin{array}{l}0.30(0.18) \\
(-0.05,0.07)\end{array}$ & $\begin{array}{l}0.05(0.02)^{\star *} \\
(0.01,0.09) \\
3.6\end{array}$ & $\begin{array}{l}0.13(0.05)^{\star \star \star} \\
(-0.22,-0.04) \\
S\end{array}$ & $\begin{array}{l}-0.07(0.03)^{\star *} \\
(-0.13,-0.02) \\
S\end{array}$ & $\begin{array}{l}-0.65(0.72) \\
(-2.05,0.75)\end{array}$ \\
\hline Benefits - psychosocial & $\begin{array}{l}-0.63(0.36)^{\star} \\
(-1.33,0.07) \\
S\end{array}$ & $\begin{array}{l}-0.08(0.04)^{\star} \\
(-0.16,0.01) \\
S\end{array}$ & $\begin{array}{l}-0.12(0.06)^{\star} \\
(-0.24,0.01) \\
S\end{array}$ & $\begin{array}{l}-0.07(0.04)^{*} \\
(-0.15,0.01) \\
S\end{array}$ & $\begin{array}{l}-0.43(0.24)^{*} \\
(-0.91,0.05) \\
86.0\end{array}$ \\
\hline Barriers - environmental & $\begin{array}{l}0.07(0.11) \\
(-0.15,0.29)\end{array}$ & - & $\begin{array}{l}-0.15(0.05)^{\star \star \star} \\
(-0.24,-0.05) \\
S\end{array}$ & $\begin{array}{l}-0.04(0.02)^{\star \star} \\
(-0.08,-0.003) \\
S\end{array}$ & $\begin{array}{l}0.09(0.09) \\
(-0.09,0.27) \\
-\end{array}$ \\
\hline \multirow[t]{2}{*}{ Barriers - motivational } & $\begin{array}{l}-0.75(0.37)^{\star \star \star} \\
(-1.47,-0.02) \\
S\end{array}$ & $\begin{array}{l}-0.09(0.04)^{\star *} \\
(-0.17,-0.01) \\
S\end{array}$ & $\begin{array}{l}-0.06(0.03)^{\star \star} \\
(-0.11,-0.01) \\
S\end{array}$ & $\begin{array}{l}0.03(0.02)^{\star} \\
(-0.002,0.065) \\
2.3\end{array}$ & $\begin{array}{l}-0.58(0.28)^{\star \star} \\
(-1.13,-0.03) \\
S\end{array}$ \\
\hline & \multicolumn{5}{|c|}{ Intervention group with parental support } \\
\hline Attitude & $\begin{array}{l}-0.92(0.49)^{\star} \\
(-1.88,0.05) \\
S\end{array}$ & $\begin{array}{l}-0.05(0.03)^{*} \\
(-0.10,0.00) \\
S\end{array}$ & $\begin{array}{l}-0.14(0.07)^{\star} \\
(-0.29,0.01) \\
S\end{array}$ & $\begin{array}{l}-0.10(0.05)^{\star} \\
(-0.21,0.004) \\
S\end{array}$ & $\begin{array}{l}-0.77(0.53)^{\star} \\
(-1.57,0.04) \\
S\end{array}$ \\
\hline Self-efficacy - physical activity at school & $\begin{array}{l}0.52(0.27)^{\star} \\
(-0.01,1.05) \\
5.7\end{array}$ & $\begin{array}{l}0.0003(0.003) \\
(-0.01,0.01) \\
-\end{array}$ & $\begin{array}{l}0.21(0.10)^{\star *} \\
(0.02,0.40) \\
10.0\end{array}$ & - & - \\
\hline
\end{tabular}

$\alpha \beta$ - product-of-coefficient estimate, mediated effect; SE - standard error; $95 \% \mathrm{Cl}-95 \%$ confidence interval; \% ME - percent of mediated effect (not computed for non-significant effects); $\mathrm{S}$ - suppression. ${ }^{*} P<0.10$; ${ }^{\star *} P<0.05 ;{ }^{* \star *} P<0.01 ;{ }^{* * \star} P<0.001$ 
statistically significant (active transportation: $-0.05 \mathrm{~min}$ day $^{-1}$; 95\% CI: $-0.12,0.02 ; P=0.182$; sporting activities: 0.07 min day $\left.^{-1} ; 95 \% \mathrm{CI}:-0.17,0.31 ; P=0.575\right)$.

\section{Discussion}

The aim of this study was to examine the psychosocial mechanisms through which a physical activity intervention, with and without parental support, yielded changes in physical activity behaviour in middle-school students. Self-efficacy for physical activity at school was found to be the only significant mediator of physical activity change. Specifically, self-efficacy for physical activity at school partly mediated the effect of the intervention on total and school-related physical activity change in the intervention group with parental support. This significant mediation effect showed that the intervention succeeded in changing self-efficacy in a positive way, which means that the adolescents were more confident that they can be physically active at school. This in turn resulted in positive changes in school-related physical activity and in total physical activity. This mediation effect was not found for the other physical activity indices. In addition, the mediation effect was only partial, which means that the intervention also resulted in a direct effect on physical activity in adolescents or that the mediators responsible for the change in physical activity were not included in the study.

The intervention consisted of two main components: an environmental component mainly focusing at increasing time, space, material and opportunities to be active; and an individual component based on personal feedback through online computer tailoring. As this multi-component intervention was implemented as a whole, it is not possible to determine which intervention component worked through which pathway. From a theoretical perspective it could be argued that making the school environment more 'activity friendly' has a direct impact upon physical activity behaviour ${ }^{35}$, but also increases self-efficacy. By increasing physical activity opportunities at school, students may feel more confident that they can be active regularly at their school. Physical activity self-efficacy may specifically be enhanced through successful experiences as special attention was given in the programme to varying the content of the physical activities offered in order to reach all students (non-competitive activities). Because emotional or physiological arousal also influences self-efficacy expectations, experiences such as fatigue, muscular strain, discomfort or pain caused by physical activity may be associated with poor performance and perceived incompetence ${ }^{37}$. These aversive emotional states threatening self-efficacy were also avoided in the programme by offering physical activities at different levels of intensity and giving students a lot of freedom to choose.
This school-based multi-component programme mainly resulted in changing school-related activity (sports and transportation) and not leisure-time activity. However, the results suggest that the home component was essential to reach this effect. An increase in parental support could have been suggested as the mechanism through which these effects were reached. In addition, the environmental component of the intervention was meant to increase the support from friends and teachers at school. However, the present study showed no mediation effects of social support.

The computer tailoring part of the intervention also included specific feedback on all the psychosocial determinants. However, only self-efficacy for physical activity at school came out as a partial mediator. Specific for self-efficacy, the personal advice focused on explaining how being active could be made 'more easy' by incorporating it in daily activities, by including active transport, and by explaining the difference between sports and physical activity. None of the other potential mediators, attitudes, social support, perceived benefits and perceived barriers, seemed to have had a positive effect. In contrast, even suppressor effects were found. This suggests that because the messages related to those potential determinants of physical activity did not change beliefs, or specific pros and cons of the behaviour in a positive way, neither resulted in increases in social support. It can be questioned whether focusing on these mainly cognitive potential mediators of behaviour, as suggested for example in the Theory of Planned Behaviour, is essential in adolescents ${ }^{38}$. However, this might not be too surprising as studies on physical activity computer-tailoring in adults also showed very minimal effects on attitudes, perceived benefits and barriers ${ }^{39}$.

Based on these results, two strategies can be followed here in the future. The first possibility is to give more attention in the intervention to increase social support and to change perceived benefits and barriers in a positive way, so that these changes can result in a more effective intervention. A second possibility is to delete the elements from the intervention that were assumed to produce these positive effects but did not, to make the intervention more parsimonious. Special attention should be given to the suppressor effect that was found for general attitudes towards physical activity in the intervention condition with parental support. The presence of this suppressor effect could be due to an actual undesired, negative effect of the intervention on the mediating variable of interest. It is possible that the intervention has led to a negative impact upon affective attitudes in this intervention group, diminishing the effect of the intervention. However, it is unclear why and how this effect could occur. In general very high baseline scores were found for the attitude measure, leading to the typical decrease with age one year later in both groups. The intervention did not succeed in reducing this decline; 
it even resulted in a somewhat steeper decline in the intervention group compared with the controls. It is possible that the adolescents were tired of hearing about physical activity and its positive effects after this 1-year intensive intervention at their school, and that this resulted in the decline in attitudes and benefits, and the increase in barriers. Future research should look further into this effect.

There are no studies to compare these results with, as to our knowledge no physical activity intervention studies have executed a full mediation analysis in children or adolescents $^{21,22}$. In adults, some support was found for self-efficacy to be a mediator among mothers with young children ${ }^{40}$. In the CATCH study (Child and Adolescent Trial for Cardiovascular Health), some evidence was also found for the importance of self-efficacy to be a possible mediator of physical activity change in elementary-school children $^{41}$. In another paper, the mediation effects of changes in psychosocial determinants of the dietary fat intake part of the present intervention were examined. As the multi-component intervention showed significant changes in fat intake in adolescent girls only, mediation effects were studied only in this subgroup ${ }^{42}$. Analyses revealed that none of the examined psychosocial factors showed a reliable mediating effect on changes in fat intake. The single-mediator model revealed a statistically significant suppression effect of perceived barriers on changes in fat intake. In the multiple-mediator model, this effect was no longer significant, which was most likely due to changes in perceived barriers being moderately related to changes in self-efficacy and attitude. The overall mediated-suppressed effect of the examined psychosocial factors was virtually zero.

Some limitations of the study need to be mentioned. First, only self-reports of physical activity and of related determinants were included. Although previous studies have shown that the physical activity and psychosocial measures have good reliability and acceptable validity ${ }^{9,24}$, they could suffer from social desirability. Second, the psychosocial determinants included as potential mediators in the present study were measured in a very general way. As suggested by Baranowski et $a l^{21}$, perhaps more specific mediation models should be tested e.g. for active transport, sport at school or physical activity in leisure time. This would allow us to tailor interventions more to the appropriate mediating variables. Finally, the comprehensive nature of our intervention does not allow conclusions about which intervention parts are responsible for which effects through which pathways ${ }^{43}$. Further research has to disentangle the relative importance of these pathways for the effectiveness of physical activity interventions.

The strength of the present study is that its longitudinal design, the presence of a control group and its overall effectiveness on physical activity indices allowed one of the first true mediation analyses in an adolescent sample.
Changes in self-efficacy for physical activity at school were found to be mediators of changes in total and school-related physical activity. Replication of the mediating properties of these variables will be needed before we can conclude that it is a consistent mediator of physical activity intervention in adolescents.

\section{Acknowledgements}

Sources of funding: This study was supported by the Policy Research Centre Sport, Physical Activity and Health funded by the Flemish Government.

Conflict of interest: There are no conflicts of interest.

Authorship responsibilities: L.H. collected most of the data; L.H. and I.D.B. did most of the writing of the manuscript; E.C. performed the statistical analyses assisted by L.H. and I.D.B.; B.D., L.M., G.C. and I.D.B. supervised the study; all authors advised on study design and interpretation, and critically reviewed and approved the manuscript.

\section{References}

1 Bouchard C, Shepard R, Stephens T. Physical Activity, Fitness And Health: Interventional Proceedings and Consensus Statement. Champaign, IL: Human Kinetics, 1994.

2 Caspersen CJ, Merrit RK, Stephens T. International physical activity patterns: a methodological perspective. In: Dishman $\mathrm{R}$, ed. Advances in Exercise Adherence. Champaign, IL: Human Kinetics, 1994; 73.

3 Steptoe A, Wardle J, Fuller R, Holte A, Justo J, Sanderman R, et al. Leisure-time physical exercise: prevalence, attitudinal correlates, and behavioral correlates among young Europeans from 21 countries. Preventive Medicine 1997; 26(6): 845-54.

4 Sallis JF. Age-related decline in physical activity: a synthesis of human and animal studies. Medicine and Science in Sports and Exercise 2000; 32(9): 1598-600.

5 Ajzen IM, Madden TJ. Prediction of goal-directed behavior: attitudes, intentions and perceived behavioral control. Journal of Experimental Social Psychology 1986; 22(5): 453-74.

6 Bandura A. Social Foundations of Thought and Action: A Social Cognitive Theory. Englewood Cliffs, NJ: Prentice-Hall, 1986.

7 Sallis JF, Prochaska JJ, Taylor WC. A review of correlates of physical activity of children and adolescents. Medicine and Science in Sports and Exercise 2000; 32(5): 963-75.

8 De Bourdeaudhuij I. Behavioural factors associated with physical activity in youth. In: Biddle S, Sallis J, Cavill N, eds. Young and Active. Young People and Health-Enhancing Physical Activity - Evidence and Implications. London: Health Education Authority, 1998; 98-118.

9 De Bourdeaudhuij I, Sallis J. Relative contribution of psychosocial variables to the explanation of physical activity in three population-based adult samples. Preventive Medicine 2002; 34(2): 279-88.

10 Timperio A, Salmon J, Ball K. Evidence-based strategies to promote physical activity among children, adolescents and young adults: review and update. Journal of Science and Medicine in Sports 2004; 7(1): S20-9.

11 Stone EJ, McKenzie TL, Welk GJ, Booth ML. Effects of physical activity interventions in youth - review and 
synthesis. American Journal of Preventive Medicine 1998; 15(4): 298-315.

12 Sallis JF, Mckenzie TL. Physical education's role in public health. Research Quarterly for Exercise and Sport 1991; 62(2): 124-37.

13 Sallis JF, Conway TL, Prochaska JJ, McKenzie TL, Marshall SJ, Brown M. The association of school environments with youth physical activity. American Journal of Public Health 2001; 91(4): 618-20.

14 Story M. School-based approaches for preventing and treating obesity. International Journal of Obesity and Related Metabolic Disorders 1999; 23(Suppl. 2): S43-51.

15 Gortmaker SL, Peterson K, Wiecha J, Sobol AM, Dixit S, Fox MK, et al. Reducing obesity via a school-based interdisciplinary intervention among youth - Planet Health. Archives of Pediatrics \& Adolescent Medicine 1999; 153(4): 409-18.

16 Sallis JF, McKenzie TL, Conway TL, Elder JP, Prochaska JJ, Brown $\mathrm{M}$, et al. Environmental interventions for eating and physical activity - a randomized controlled trial in middle schools. American Journal of Preventive Medicine 2003; 24(3): 209-17.

17 Simon C, Wagner A, DiVita C, Rauscher E, Klein-Platat C, Arveiler $\mathrm{D}$, et al. Intervention centred on adolescents' physical activity and sedentary behaviour (ICAPS): concept and 6-month results. International Journal of Obesity and Related Metabolic Disorders 2004; 28(Suppl. 3): S96-103.

18 Haerens L, De Bourdeaudhuij I, Maes L, Cardon G, Deforche B. School based randomized controlled trial of a physical activity intervention in 11 to 15 year olds. Journal of Adolescent Health 2007; 40(3): 258-65.

19 Green L, Kreuter M. Health Promotion Planning: An Educational and Ecological Approach. Mountain View, CA: Mayfield, 1999.

20 McKenzie TL, Smeltzer JL. Planning, Implementing and Evaluating Health Promotion Programs: A Primer. Boston, MA: Allyn and Bacon, 2001.

21 Baranowski T, Anderson C, Carmack C. Mediating variable framework in physical activity interventions - how are we doing? How might we do better? American Journal of Preventive Medicine 1998; 15(4): 266-97.

22 Lewis BA, Marcus BH, Pate RR, Dunn AL. Psychosocial mediators of physical activity behavior among adults and children. American Journal of Preventive Medicine 2002; 23(2 Suppl.): 26-35.

23 Haerens L, Deforche B, Maes L, Stevens V, Cardon G, De Bourdeaudhuij I. Body mass effects of a physical activity and health food intervention in middle schools. Obesity Research 2006; 14(5): 847-54.

24 Ainsworth BE, Haskell WL, Whitt MC, Irwin ML, Swartz AM, Strath SJ, et al. Compendium of Physical Activities: an update of activity codes and MET intensities. Medicine and Science in Sports and Exercise 2000; 32(9 Suppl.): S498-516.

25 Philippaerts RM, Matton L, Wijndaele K, Balduck AL, De Bourdeaudhuij I, Lefevre J. Validity of a physical activity computer questionnaire in 12- to 18-year-old boys and girls. International Journal of Sports Medicine 2006; 27(2): $131-6$.

26 De Bourdeaudhuij I, Philippaerts R, Crombez G, Matton L, Wijndaele K, Balduck AL, et al. Stages of change for physical activity in a community sample of adolescents. Health Education Research 2005; 20(3): 357-66.
27 Haerens L, De Bourdeaudhuij I, Maes L, Vereecken C, Brug $\mathrm{J}$, Deforche B. The effects of a middle-school healthy eating intervention on adolescents' fat and fruit intake and soft drinks consumption. Public Health Nutrition 2007; 10(5): 443-9.

28 Vandelanotte C, De Bourdeaudhuij I. Acceptability and feasibility of a computer-tailored physical activity intervention using stages of change: project FAITH. Health Education Research 2003; 18(3): 304-17.

29 Vandelanotte C, De Bourdeaudhuij I, Sallis JF, Spittaels H, Brug J. Efficacy of sequential or simultaneous interactive computer-tailored interventions for increasing physical activity and decreasing fat intake. Annals of Behavioral Medicine 2005; 29(2): 138-46.

30 Sallis JF, Hovell MF, Hofstetter CR, Barrington E. Explanation of vigorous physical-activity during 2 years using social-learning variables. Social Science \& Medicine 1992; 34(1): 25-32.

31 Krull JL, MacKinnon DP. Multilevel modeling of individual and group level mediated effects. Multivariate Behavioral Research 2001; 36(2): 249-77.

32 MacKinnon DP. Contrasts in multiple mediator models. In: Rose JS, Chassin L, Presson CC, Sherman SJ, eds. Multivariate Applications in Substance Use Research New Methods for New Questions. Mahwah, NJ: Erlbaum, 2000; $141-60$.

33 MacKinnon DP, Fairchild AJ, Fritz MS. Mediation analysis. Annual Review of Psychology 2007; 58(1): 593-14.

34 Bollen KA. Total direct and indirect effects in structural equation models. In: Clogg CC, eds. Sociological Methodology. Washington, DC: American Sociological Association, 1997; 37-69.

35 Cohen J. Statistical Power Analysis for the Behavioural Sciences, 2nd ed. Hillsdale, NJ: Erlbaum, 1988.

36 Sallis JF, Owen N. Ecological Models of Health Behavior. San Francisco, CA: Jossey-Bass, 2002.

37 Duncan TE, Mcauley E. Social support and efficacy cognitions in exercise adherence - a latent growth curve analysis. Journal of Behavioral Medicine 1993; 16(2): 199-218.

38 Connor M, Norman P. Predicting Health Behavior: Research and Practice with Social Cognition Models. Buckingham: Open University Press, 1996.

39 Spittaels H, De Bourdeaudhuij I, Brug J, Vandelanotte C. Effectiveness of an online computer-tailored physical activity intervention in a real-life setting. Health Education Research 2007; 22(3): 385-96.

40 Miller YD, Trost SG, Brown WJ. Mediators of physical activity behavior change among women with young children. American Journal of Preventive Medicine 2002; 23(2): 98-103

41 Edmundson E, Parcel GS, Feldman HA, Elder J, Perry CL, Johnson C, et al. The effects of the child and adolescent trial for cardiovascular health upon psychosocial determinants of diet and physical activity behavior. Preventive Medicine 1996; 25(4): 442-54.

42 Haerens L, Cerin E, Deforche B, Maes L, De Bourdeaudhuij I. Explaining the effects of a 1-year intervention promoting a low fat diet in adolescent girls: a mediation analysis. International Journal of Behavioral Nutrition and Physical Activity 2007; 2nd revision.

43 Baranowski T, Jago R. Understanding the mechanisms of change in children's physical activity programs. Exercise and Sport Sciences Reviews 2005; 33(4): 163-8. 